\title{
BIOGRAFIA DE OLIVIER TONI
}

\author{
Rubens Russomanno Ricciardi \\ Universidade de São Paulo \\ rubensricciardi@gmail.com
}

compositor, maestro, professor e fagotista paulistano George Olivier Toni (1926-2017) foi um dos nomes centrais da música brasileira e, em especial, da paulista, na segunda metade do século XX.

Aluno de Camargo Guarnieri e Hans-Joachim Koellreutter, foi definido, certa vez, por Gilberto Mendes como "síntese dialética do neofolclorismo e das linhas de Darmstadt", as principais vertentes da música moderna no Brasil.

Fagotista da Orquestra Sinfônica Municipal de São Paulo (OSMSP), ali atuou sob a batuta de vários regentes, entre os quais Heitor Villa-Lobos, de quem recebeu importante influência.

Em sua carreira de maestro destacam-se as inúmeras vezes, sempre a convite de Eleazar de Carvalho, nas quais Olivier Toni regeu a Orquestra Sinfônica do Estado de São Paulo (Osesp) e a Orquestra Sinfônica de Porto Alegre (Ospa), além de outras importantes orquestras brasileiras.

incansável espírito inovador a bem do serviço público e do desenvolvimento da música em São Paulo e no Brasil levou Toni a fundar instituições que, hoje, estão entre as mais relevantes da capital paulista. Sempre defendendo e tendo em vista o ensino público e gratuito da mais alta qualidade em seus empreendedorismos, Olivier Toni é fundador da Escola Municipal de Música de São Paulo (com apoio do então prefeito Faria Lima), Orquestra Sinfônica Jovem Municipal de São Paulo (que, posteriormente, teve seu nome trocado para Orquestra Experimental de Repertório), Orquestra de Câmara de São Paulo (hoje não mais em funcionamento, mas que fez história em sua época), do Departamento de Música da Escola de Comunicações e Artes da Universidade de São Paulo (ECA-USP) (do qual foi chefe por muitos anos, tornando-se 
seu primeiro professor titular, sempre em Regime de Dedicação Integral à Docência e à Pesquisa), das Bienais de Música de São Paulo (um dos grandes eventos musicais na história da USP), da Orquestra Sinfônica da Universidade de São Paulo (Osusp) e da Orquestra de Câmara da USP (Ocam).

É fundador e sempre dirigiu o Festival de Música de Prados (em trabalho conjunto de décadas com o igualmente saudoso maestro pradense Adhemar Campos Filho).

Pela USP em Ribeirão Preto, Olivier Toni sugeriu e incentivou, em 2011, a fundação da USP-Filarmônica. Já havia sido também um dos principais articuladores do Curso de Música (de 2001 a 2010 atrelado à ECA e, desde 2011, à Faculdade de Filosofia, Ciências e Letras de Ribeirão Preto da USP), apoiando decisivamente seu próprio projeto de fundação. Toni também chegou a reger por diversas vezes a Orquestra Sinfônica de Ribeirão Preto (OSRP) nos anos anteriores à fundação da USP-Filarmônica, nossa orquestra acadêmica que ele só não chegou a reger porque a saúde já não mais the permitiu. Mas Toni ainda assim presidiu a primeira seleção de bolsistas da USP-Filarmônica, em 2011.

Olivier Toni concentrou sua atuação acadêmica em duas frentes. De um lado, a pesquisa e o resgate da música mineira colonial e, de outro, a música contemporânea. Nesse sentido, Toni é um pilar fundamental da história do próprio Festival Música Nova (com sede na USP de Ribeirão Preto desde 2012), com participação decisiva em inúmeras edições como compositor ou maestro, bem como foi indiscutivelmente o principal líder do grupo que redigiu o Manifesto Música Nova, em 1963, mesmo que seu nome não conste entre os signatários.

Destaca-se em sua atuação como professor e mestre, anteriormente e já depois na USP, tanto em São Paulo como em Ribeirão Preto, a formação de nomes importantes da música brasileira, tais como Gilberto Mendes, Rogério Duprat, Régis Duprat, Willy Corrêa de Oliveira, Mario Ficarelli, Rufo Herrera, Carole Cubernikoff, Paulo Cesar Chagas, Paulo Sérgio Guimarães Álvares, Marcos Câmara de Castro, Silvia Maria Pires Cabrera Berg, Rubens Russomanno Ricciardi, Cláudio Cruz e Lucas Eduardo da Silva Galon, entre tantos outros. Seu último local de atuação 
como professor, já emérito da ECA-USP, foi a USP de Ribeirão Preto, onde deu aulas por alguns anos, colaborando diretamente na consolidação do novo curso, tendo ainda sido responsável direto pela formação de novos valores ribeirão-pretanos.

\section{Sobre o autor}

Prof. Dr. Rubens Russomanno Ricciardi é Professor titular do Departamento de Música FFCLRP-USP, compositor, maestro e diretor artístico da USP-Filarmônica. É Coordenador do Núcleo de Pesquisa em Ciências da Performance em Música NAP-CIPEM, Professor responsável pelo Festival Música Nova "Gilberto Mendes" e pelo projeto USP-MúsicaCriança. 